Mirjam Künkler. (Ph.D., Columbia University) Assistant Professor in the Department for Near Eastern Studies at Princeton University, USA. She has published on religion-state relations and Islamic thought in 20th century Iran and Indonesia, and edited with Alfred Stepan, Indonesia, Islam and Democracy, Columbia University Press (2013), and with John Madeley and Shylashri Shankar, A Secular Age: Beyond the West, (2015). Her articles have appeared or are forthcoming in the journals Comparative Studies of Society and History, Journal of the Royal Asiatic Society, Journal of Law and Religion, Democratization, Politics and Religion, Journal of International Affairs, Party Politics, as well as in edited volumes.

Contact: kuenkler@princeton.edu

John Madeley. Research Associate of the Department of Government at the London School of Economics and Political Science. His research focuses on explaining the complexity and diversity of patterns of religionstate-society relations across Europe's 50-odd state jurisdictions and on developing a political science lexicon for describing and analyzing the dynamics of these relations. His books include Church and State in Contemporary Europe: the Chimera of Neutrality (Cass 2003), co-edited with Zsolt Enyedi, and Religion, Politics and Law in the European Union (Routledge 2009), co-edited with Lucien Leustean.

Contact: j.madeley@1se.ac.uk

\title{
A SECULAR AGE BEYOND THE WEST: \\ FORMS OF DIFFERENTIATION IN AND AROUND THE RELIGIOUS FIELD
}

\author{
Mirjam Künkler \\ Princeton University
}

John Madeley

The London School of Economics and Political Science

Reception date October $28^{\text {th }}$ 2014; Acceptance date November $11^{\text {th }} 2014$. This article is the result of research activities held at the Department for Near Eastern Studies at Princeton University in collaboration with the Department of Government at the London School of Economics and Political Science. 


\begin{abstract}
The article addresses the relevance of Charles Taylor's analysis in his influential magnum opus A Secular Age (2007) to those parts of the world which are not included in the North-Atlantic world on which he concentrates. It does so by discussing issues arising from case studies of Asian, African and Middle Eastern contexts where the impact of different types of secularity varies in terms of its incidence, intensity and scope, sometimes paralleling, often contrasting those developments Taylor found to be key in the emergence of a secular age in the West. By contrast with Taylor's analysis, a common feature of these studies is the stress placed upon the role of political actors in promoting or contesting the secularity of the public sphere. It is argued that a useful approach to making sense of the great variety of patterns identified can be found by combining insights from Niklas Luhmann and Pierre Bourdieu in order to construct a matrix illustrating the types and levels of differentiation and contestation in and around the religious field.
\end{abstract}

\title{
Keywords
}

Religion, politics, secularization, state

\section{Resumen}

\section{Palabras clave}

Religión, política, secularización, Estado. 
Based on an international research cluster of country specialists interested in the nexus between politics and religion in countries of Asia, Africa and the Middle East, we have edited, together with Shylashri Shankar, a volume that compares the place of religion and the secular in countries outside the West. ${ }^{1}$ All contributors took as their starting point Charles Taylor's "A Secular Age" (2007), in which the author argues that the widespread availability of an option of not believing first evolved in the North Atlantic world. He examines the processes by which this option emerged, mostly by focusing his inquiry ${ }^{2}$ on developments in philosophy and religion (specifically, Western Christianity), while social, economic, and political developments for a large part remain back stage. In the following, we summarize some of the lessons our contributors have drawn from their case studies, sometimes paralleling, often contrasting those developments Taylor found to be key in the emergence of a secular age in the West. We close with a sociological framework through which contestations around religion and state can be systematically schematized and compared.

\section{A Secular Age}

The case studies of our volume focus on the patterns of religion-state relations in the modern era, which each in their own ways, have created particular secularities, but often not in the sense Taylor finds most important. Taylor identifies three notions of Secularity, of which he is most interested in the third. The first notion is that of the classic differentiation theory ${ }^{3}$ : Secularity I emerges as religion is evacuated from public life and its related areas, in particular political authority, law, science, the bureaucracy, and the economy. Secularity II is the notion describing the decline of religious belief and practice, something sociologists argued was the case in the Europe of the 1960s and which they predicted would be a universal trend. Today, European Secularity II, if religion as such really has been on the decline there at all, is regarded as the global exception rather than the rule. ${ }^{4}$ But it is a third notion that particularly interests Taylor. Under Secularity III he understands a condition in which it is possible to not believe, and still aspire to live a fulfilled life. Crucially, in this third state the nature of social and legal conditions allows for the choice not to believe: a secular age is one in which societies accept non-belief as much as belief and do not proceed from the assumption that only a believer can lead a fulfilled life. This shift is reached by "a series of new departures," in which earlier forms of religious life are dissolved and new ones created. It is evident in the way the location of meaning is perceived: in the pre-modern world, structures and traditions of meaning already existed around us, but in the modern world, meaning is endogenous. What was once a human's "porous self" (going against God was not an option because life was lived in a social world peopled by spirits and fellow human beings) has been replaced by a "buffered self": a self aware of the possibility of disengagement. Further departures include the sense of time, which has changed radically from one including the higher time of eternity to time seen as structured and quotidian, and the notion of the place of man from living in an enveloping cosmos to being merely situated in the universe, taking one from a fear of the dead to a fear of death itself. This condition of Secularity III, according to Taylor, developed uniquely in the North

\footnotetext{
${ }^{1}$ M. Künkler, J. Madeley, S. Shankar (eds.), A Secular Age Beyond the West, Cambridge University Press, Cambridge Studies in Social Theory, Religion and Politics, 2016.

${ }^{2}$ C. Taylor, A Secular Age. Belknap Press, Harvard, 2007.

${ }^{3}$ J. Casanova, Public Religions in the Modern World. University of Chicago Press, Chicago, 1994.

${ }^{4}$ G. Davie, Europe: the Exceptional Case: Parameters of Faith in the Modern World, Darton Longman \& Todd, 2002.
} 
Atlantic world, where it prevails today, and he leaves open the question whether it could be, or has in the meantime been, realized in other parts of the world. ${ }^{5}$

This is where our volume takes its starting point. The contributors examine, each in their geographic area of expertise, whether, to what extent and how, a secular age in Taylor's sense may have eventuated, and if /where it has not, what other forms of secularity might be detected.

\section{The cases}

The volume stretches across a large geographical range beyond Taylor's North Atlantic world, encompassing case studies of modern China, Japan, Russia, Indonesia, India, Pakistan, Iran, Egypt, Turkey, Morocco and Israel. In an attempt to transcend a simple dichotomy of West and non-West, which often boils down to elaborations on Christian-Muslim or West-East contrasts, we selected case that ensure diversity in three principal respects.

Firstly, the chapters discuss societies where monotheistic, polytheistic, and nontheistic belief systems varyingly predominate. In addition, rather than featuring only one or two Muslim cases, on the basis of which broad conclusions about the "Muslim world" are then formulated, the collection includes a diversity of several case studies from the Muslim world, both Arab and non-Arab, from the Middle East, South Asia, Southeast Asia, and North Africa, and with considerable intra-Islamic diversity where variously Sunni, Shi'a and Sufi currents dominate. The volume also contains a chapter on Israel, which as the only predominantly Jewish country rarely receives attention in comparative studies of secularity. Furthermore, the collection includes a case of that significant part of Christianity which Taylor omits, i.e. Eastern/Orthodox Christianity, and as such, the country that has most influenced the development of religion in the $20^{\text {th }}$ century Orthodox Christian world, Russia. Finally, with discussions of societies whose majorities are Confucian (China), BuddhistShinto (Japan), and Hindu (India), the volume includes predominantly polytheist and nontheist cases.

Secondly, the countries differ in their arrangements for the relationship between religion and law; Israel, India and the Muslim states place a strong emphasis on religious law in some or all domains, while in China, Japan and Russia, questions about the jurisdiction of religious law play little part in the secularization debates.

Thirdly, the country cases vary in terms of public participation and the open contestation of power: while some governments, such as in China and Iran, are authoritarian and largely shielded from public pressure and accountability, others are long-standing democracies, such as Japan and India, where questions of religious freedom and religious identity may determine electoral outcomes.

\footnotetext{
${ }^{5}$ Taylor in general acknowledges that there may be multiple secularities, but it is not clear which Secularity (I, II, or III) he has in mind when he writes "secularity, like other features of 'modernity' (. . .) find rather different expression, and develop under the pressure of different demands and aspirations in different civilizations" (p. 21).
} 
Thus, the cases brought together in the volume showcase diversity in three dimensions: religious makeup of the population, the status of religious law, and the nature of the political regime.

\section{A Secular Age outside the West}

A first major conclusion arising from the comparative analysis is that contestations around Taylor's Secularity I (the evacuation of religion from public life) occupy a much more prominent place than was the case in Taylor's narrative of the Christian West. Such contestations around Secularity I are particularly apparent in the Muslim world and Israel, as both Islam and Judaism may be interpreted as placing more demands on public law than is the case in Christianity, Buddhism or Hinduism. We refer to this as relating to the "burdening" of religion by state policies: with the expansion of the regulation of private and public space by the consolidating modern state, religions are differentially impacted, depending on how much of this regulation would historically have been undertaken on the basis of religious interpretation. In all Muslim countries included in this volume, as well as among Jewish communities, the administration of both personal law and education was undertaken by religious elites prior to the emergence of the modern state. With the advent of the latter, the transplantation of Western legal systems and often the introduction of Western-style constitutions, these competencies were stripped from religious authorities. By contrast, by the time modern political and legal institutions had been introduced in the societies of Latin Christendom, independent religious elites had ceased to hold the monopoly of education and law. In what became referred to as Hinduism, such a monopoly had never existed, any more than it did in Buddhism. Therefore, the degree of burdening differs markedly across different geographic and civilizational contexts, depending on the realms regulated by religion prior to the emergence of the modern state. Accordingly, in Islam it is religious law that experiences profound interference by the $20^{\text {th }}$ century state, while in China's Confucian traditions, it is education. The importance of capturing this variation (how expansive is the contact surface of religion that can be impacted by state policies?) in an account of Secularity I becomes apparent especially, and possibly only, when comparing such encounters across various monotheistic and polytheist, as well as non-theistic traditions.

It is a remarkable fact that the word 'secularism,' as a political project so intricately bound up with Secularity I, scarcely occurs in the 776 main pages of text or in the 71 pages of notes of $A$ Secular Age. This is especially worthy of note given the fact that Taylor has also published influential essays both before and after on 'Modes of Secularism, ${ }^{6}$ 'The Meaning of Secularism, ${ }^{7}$ and 'Why We Need a Radical Redefinition of Secularism. ${ }^{8}$ In 'Western Secularity', ${ }^{9}$ which reprises the argument of A Secular Age, Taylor uses both terms, secularity and secularism, freely if not interchangeably. For all that it concentrates on the relatively recent emergence of Secularity III

\footnotetext{
${ }^{6}$ C. Taylor, "Modes of Secularism", in R. Bhargava (ed.), Secularism and its Critics, Oxford University Press, Delhi, 1998, pp. 31-53.

${ }^{7}$ C. Taylor, "The Meaning of Secularism", in The Hedgehog Review",12, 3, 2010, pp. 23-34.

${ }^{8}$ C. Taylor, "Why We Need a Radical Redefinition of Secularism", in E. Mendieta, J. VanAntwerpen (eds.) , The Power of Religion in the Public Sphere, Columbia University Press, New York, 2011, pp. 34-59.

${ }^{9}$ C. Taylor, "Western Secularity" in G. Calhoun, M. Juergensmeyer, J. Van Antwerpen (eds.), Rethinking Secularism, Oxford University Press, London, 2011, , pp. 31-53.
} 
in the North Atlantic world, A Secular Age does contain a number of important claims about major changes in Secularity I over the last half millennium in the West, as the passing references to the Protestant and Catholic Reformations, the 30 Years War, and the English, American, French and Russian revolutions illustrate. ${ }^{10}$ Taylor's focus is, however, more on explicating and teasing out the implications of the work of important writers such as Hobbes, Grotius, Locke, Rousseau, Burke and Marx - concentrating attention either on the sense they made of the great historical conjunctures through which they lived or on their contributions to the development of thought about religion, the state and secularity. Despite the incidental reference to these critical historical junctures his discussion was focused much less on the institutional-political changes, which occurred on the back of those events and their role in advancing the onset of the present 'secular age.,11

Relatedly, the case studies of our volume by and large confirm Nikkie Keddie's observation that secularization in "the non-Christian and non-Western worlds [which] are generally omitted from the debate [on secularization] [has] been more influenced by government action than by autonomous societal changes". ${ }^{12}$ In examining conditions and developments in the societies under review, our contributors have been unable to sidestep the conflicts surrounding the place of religion in public life and the more or less provisional settlements which have eventuated. For Keddie this priority of the political, as we might call it, deserves recognition because "the very strengthening of a state demanded by modern economies requires considerable state control of public education, civil law, welfare and other spheres that is more secular than anything that existed in the past". ${ }^{13}$

Second, Taylor's decision to sidestep the debates around rival conceptions of religion, while understandable and defensible in the context of the exclusively Western focus of A Secular Age, cannot be finessed in the same way when it comes to identifying and explaining the incidence of secularity in non-Western contexts. One ostensible reason why questions of definition could be set aside in the Western context is that the very category 'religion' can be seen, as scholars from Cantwell Smith to Talal Asad have long argued, as a distinctively Western concept. Despite the fact that - or perhaps because - the concept was heavily informed by Western perceptions of colonial subjects, it is one which cannot readily be used outside the contexts of Latin Christendom without careful qualification. Gregory Starrett identifies among the first Western students of comparative religion in the nineteenth century the setting of a distinctive 'Protestant tendency to see religion primarily as a system of beliefs, doctrines, and dogmas. ${ }^{14}$ Alternative conceptions which privilege traditional practices and traditions as key defining features of religion implicitly challenge

\footnotetext{
10 And even further back, references are made to such other critical junctures as Jaspers' Axial Age, the Investiture Crisis and the 1215 Lateran Council. See S. N. Eisenstadt, The Origins and Diversity of Axial Age Civilizations, SUNY Press, 1986; and H.J. Berman, Law and Revolution: The Formation of the Western Legal Tradition, Harvard University Press, 1983.

11 It can even be claimed that Taylor underplays the significance of these historical conjunctures, especially those which turned on papal claims to precedence over temporal officeholders. The significance of the decisive critical juncture(s) of the Reformation and Counter-Reformation with the ensuing so-called 'religious wars' up to 1648 should perhaps be seen as involving the final, critical inversion of the hierarchical relationship between the religious and the secular spheres in the West. Talal Asad refers to the 'remarkable ideological inversion' involved in this shift (T. Asad, Formations of the Secular: Christianity, Islam, Modernity, Stanford University Press, 2003: 192).

${ }^{12}$ N. R. Keddie, "Secularism and the State: Towards Clarity and Global Comparison", New Left Review, 1997, 226: 21$40,22$.

${ }^{13}$ Ibid., 226:21-40, 24.

${ }^{14}$ G. Starrett, Mass Culture and Modernism in Egypt, American Ethnologist, Volume 26, Issue 2, 1999, p. 149-50.
} 
such restrictively Latin Christian notions of secularity just as much as of religion itself. ${ }^{15}$ They also challenge Taylor's key notions of different forms of secularity, which are necessarily parasitic on an understanding of religion as defined in Western Christianity. ${ }^{16}$ In several cases, the engagement with the Western Christian concept of religion has, in the twentieth century if not before, been necessitated by legal requirements to translate into local languages and legal practice various international obligations, for example, the commitments to respect the terms of the UN Declaration of Human Rights guaranteeing religious freedom. As if to confirm the observation, Casanova makes the linguistic point that 'one of the most important global trends is the globalization of the category of 'religion' itself and the binary classification of 'religious/secular,' that it entails'. ${ }^{17}$ But as he also goes on to point out, 'when people around the world use the same category of religion, they actually mean very different things. The actual concrete meaning of whatever people denominate as 'religious' can only be elucidated in the context of their particular discursive practices. ${ }^{18}$ The chapters on China and on Japan provide insight in how the actual business of translation of key terms into the appropriate vernaculars has presented particular problems. In both countries, a local term for the concept of 'religion' only entered the vernacular when trade, peace and concession treaties with Western powers necessitated it. The problem has hardly been less severe in India, despite the status of English as a 'subsidiary official language'. T.N. Madan quotes an eloquent observation from a nineteenth century Indian intellectual: 'You can translate a word by a word, but behind the word is an idea, the thing the word denotes, and this idea you cannot translate, if it does not exist among the people in whose language you are translating'. ${ }^{19}$

Third, the hermeneutic narrative of A Secular Age identifies certain features which are claimed to be, on the one hand, instinct to Western Christianity, and, on the other, not to be shared by other major world religions, for example: a perennial 'drive to reform', a lack of tolerance for what Taylor calls 'complementarity', and a deep antipathy to all forms of traditional magic. ${ }^{20}$ For Taylor, all three of these have over the centuries undermined the cultural viability of transcendentalist intimations, beliefs, and practices, and promoted the efflorescence of modern immanentist forms of secularity in their place. ${ }^{21}$ His implied view of the non-West's 'otherness' can be read off from his insistence on Western exceptionalism by virtue of which world regions beyond

\footnotetext{
${ }^{15}$ M. Riesebrodt, "Religion in a global perspective", in M. Jurgenmeyer (ed.), Global Religions. An Introduction, Oxford University Press, Oxford, 2003, pp. 95-109; B. S Turner, Religion and Social Theory, Sage, London, 1991 ; T. Asad, Formations of the Secular, p. 192.

16 Taylor indicates early on that he is aware of the danger of reducing lived religion to matters of belief (pp. 4-5) but from A Secular Age's first section 'The Bulwarks of Belief' to later sustained discussion of the conditions of belief, his study is overwhelmingly concentrated on this aspect of religion, albeit on the basis of an explicitly extended notion of what belief entails. 'Belief is less a cognitivist stance than a deep, almost unconscious enmeshment in a thick texture of Christian norms, values and practices. So extensive is the force wielded by these norms that even atheists and nonbelievers cannot escape it....' p. 284.

${ }^{17}$ Casanova in See Warner, Michael, Jonathan Van Antwerpen and Craig Calhoun (eds), Varieties of Secularism in a Secular Age, Harvard University Press, Cambridge (Mass.), 2010, 62.

${ }^{18}$ Ibid.

${ }^{19}$ T.N. Madan, Modern Myths, Locked Minds: Secularism and Fundamentalism in India, Oxford University Press, Cambridge, 1998, 308.

${ }^{20}$ Taylor refers to a complementary of 'the demands of the total transformation which the faith calls to, and the requirements of ordinary ongoing human life'. See ASA, 44.

21 For most 'orthodox' theorists also secularization emerged as a result of dynamics internal to the West - it represented a progressive emancipation from religious authority driven forward by a raft of modernizing developments such as industrialization, urbanization and societal rationalization. Characteristically, for Taylor it is seen to emerge on the back of internal changes motivated by changing religious sensibilities and associated drives toward 'reform after reform'.
} 
the West necessarily appear as if in a sort of photographic negative of the West. As the chapters in our volume graphically illustrate, however, the relative absence of 'Western features' is hardly the most salient characteristic that emerges from a general comparative survey. Indeed, the actual presence of features originating in the West on the back of 'imperial encounters' forms an important part of all the case studies. The modalities of the Western impact have been shown to vary considerably from direct imposition by a series of imperial masters (India, Pakistan, Indonesia, Egypt, Palestine/Israel) to secularist transformation projects adopted by indigenous elites in imitation of Western models (Turkey, Iran, even the USSR, and late Qing and Republican China). In addition, the pressures to adhere to Western-led models of religious freedom (for example, in post-WWII Japan) or to incorporate Western legal codes and administrative systems (in the case of Morocco), have also clearly been shown to affect, if not determine, patterns of secularization. ${ }^{22}$

In this, our volume confirms John Bowen's argument that studies of secularization as a long-term process 'can stretch to encompass much of the rest of the world, but only by tracing a genealogy from the West to the Rest, through processes of colonial or neo-colonial domination, or alternatively processes of movement and borrowing'. ${ }^{23}$ José Casanova concurs: 'It just happened that the particular, Christian, Western European dynamic of secularization became globalized with the expansion of European colonialism, and with the ensuing global expansion of capitalism, of the European system of states, of modern science, and of modern ideologies of secularism' ${ }^{24}$ While a large part of the story of secularity outside the North Atlantic world must take account of this tale of the import-export of Western secularity, however, the more interesting story is often to be found in how such models of religion-state relations have been re-shaped and re-defined in local contexts.

A fourth important insight that emerges is that the state should not be seen as necessarily or inherently secular (contra Olivier Roy, for example). Instead, the state - in the West as well as beyond it - appears as typically both an actor and a stake in the various struggles around the role of religion in public life, even to the point of conjuring a degree of its own sacralization in the resulting outcomes. It can be argued that to make the otherwise common assumption that the state is by definition secular - and so itself immune to secularization and/or sacralization - involves a category error: states should instead be regarded as more or less secular, and more or less religious, whether along a single dimension or on a number of cross-cutting dimensions. ${ }^{25}$

\footnotetext{
22 Warner et al note the 'striking fact' of Taylor's non-engagement with Talal Asad, Ashis Nandy, Rajeev Bhargava, and others who concentrated on the relation between the dominant secular frameworks of modernity and those religious communities that encountered the secular primarily through colonial domination. See Warner, Michael, Jonathan Van Antwerpen and Craig Calhoun (eds.), Varieties of Secularism in a Secular Age, Harvard University Press, Cambridge, (Mass.), 2010, 25.

${ }^{23}$ J. R. Bowen. 'Secularism: Conceptual Genealogy or Political Dilemma?' Comparative Studies in Society and History, Volume 52, Issue 03, July 2010, 681. Notably, this is not to suggest that there are no indigenous sources to secularity and no guiding ideas in local intellectual traditions that have shaped paths of secularization in societies outside the West. But it is to say that secularization cannot factually be isolated from encounters with the West, and institutional models that have emerged in all cases covered in the volume have been partial products of institutional diffusion, and sometimes imposition by colonial or imperial encounters.

${ }^{24}$ J. Casanova, Rethinking Secularization: A Global Comparative Perspective, "The Hedgehog Review", 2006, pp. 7$22,13$.

${ }^{25}$ Cfr. A. Stepan, Arguing Comparative Politics, Oxford University Press, New York, 2001; J. Madeley, "Unequally yoked: the antinomies of Church-State separation in Europe and the USA", in European Political Science, 8 (3), pp. 273-288.
} 
In focusing on key episodes over the last 150 years during which the mutual articulation of the religious and the secular was contested between rival forces and stakeholders, the case studies have thrown light on what can be seen as local instances of a perennial and ostensibly universal problem. In Bowen's terms, this is the essentially political problem of 'how states manage to encompass or govern religions while not denying their truth claims or social rights,' a problem which is seemingly found whenever and wherever 'rulers seek to create a space of governance above that wielded by religious authorities. ${ }^{26}$ With his focus on the conceptual genealogy of secularity describing 'a set of historical processes that characterize the modern age (at least for some of the world)', Taylor's own analysis downplays this 'dilemma of government. ${ }^{27}$ In contrast to Taylor's account, the different patterns of successive provisional settlements of this perennial political problem at the interface of religion and secular power has formed the key focus of our case studies.

\section{Patterns of Conflict in and around the Religious Field}

All of the case studies in the volume give weight to the argument prevalent among political sociologists that secularity is a result of social conflicts. As such conflicts are universal and not inherently/structurally different among world religions, we agree with Casanova (2006:19) that the concepts of secularization and secularity make sense "as an analytical framework for a comparative research agenda that aims to examine the historical transformations of all world religions under conditions of modern structural differentiation."

In the volume Philip Gorski proposes to supplement Taylor's approach to the aetiology of Western secularity by borrowing from the conceptual toolboxes of Niklas Luhmann and Pierre Bourdieu. ${ }^{28}$ This way, Gorski suggests, conflicts over the place of religion in public life can be usefully schematized. The sociologist Niklas Luhmann developed and applied his social systems theory to a number of macro-sociological processes. Many of his later writings have only posthumously been published, and are just now being translated into foreign languages, including

\footnotetext{
${ }^{26}$ J. R. Bowen. “Secularism: Conceptual Genealogy or Political Dilemma?”, p. 681.

${ }^{27}$ Ibid.

${ }^{28}$ Gorski's is only one approach to analyzing the underlying patterns of contestation. An alternative schema is proposed by Wohlrab-Sahr and Burchardt who systematize conflict not around forms of differentiations and across different fields, but around four issue areas: “(1) the problem of individual freedom vis-à-vis dominant social units, be they groups or the state; (2) the problem of religious heterogeneity and the resulting potential or actual conflictuality; (3) the problem of social or national integration and development; and (4) the problem of the independent development of institutional domains." The authors state "It is clear that most of these problems are closely associated to the formation of modern societies and states and the ideas on which they are founded, whereas at least the second also arises in pre-modern societies. It is no accident that reflections on pre-modern sources of modern secularity generally begin here." M. Wohlrab-Sahr and M. Burchardt, Multiple Secularities: Towards a Cultural Sociology of Secular Modernities in "Comparative Sociology", 11: 8, 2012, pp. 875-909, 887.
} 
English, among them his "Die Religion der Gesellschaft" ('The Religion of Society'). In his neofunctional differentiation theory, four different forms of societal differentiation drive human development. These are:

1. segmentary differentiation, as in clan divisions among hunter-gatherers

2. center/periphery differentations, as in ancient imperial systems

3. stratificatory differentations, as in ascriptive hierarchies of medieval Europe

4. functional differentations, as in the modern differentiation of spheres of state, economy, science etc

As Gorski suggests, Luhmann's concepts can be used to describe the "internal differentiation" of the religious systems of modern societies as well as the (external) differentiation of the religious and political systems. Functional differentiation has been a central feature of almost all secularization theorizing; a feature, furthermore, which Casanova has identified as representing 'the still defensible core' of the theory of secularization': 'the conceptualization of the process of societal modernization as a process of functional differentiation and emancipation of the secular spheres - primarily the state, the economy, and science - from the religious sphere and the concomitant differentiation and specialization of religion within its own newly found religious sphere. ${ }^{29}$ Taylor echoes this essentially Weberian insight in his description of the results of this process in the West: 'we function within various spheres of activity - economic, political, cultural, educational, professional, recreational - the norms and principles we follow, the deliberations we engage in, generally don't refer us to God or to any religious beliefs; the considerations we act on are internal to the 'rationality' of each sphere - maximum gain within the economy, the greatest benefit to the greatest number in the political arena, and so on. ${ }^{30}$ This modern pattern is contrasted with the situation in earlier times when the Christian faith 'laid down authoritative prescriptions, often through the mouths of the clergy. ${ }^{31}$ His reference to the authoritative character of religious prescriptions in earlier times suggests an important aspect of differentiation, which should perhaps be seen as not so much a matter of horizontal differentiation - the development of autonomous spheres each governed by its own 'rationality' - but, instead, as a radical shift in the vertical or authority relationship between the religious and the secular spheres, in casu the final establishment of the state's precedence over religious officials and/or institutions.

Using Luhmann's distinctions between the four types of differentiation, the conflicts attending the early-modern birth of the confessional state and its eventual, uneven devolution after the 1789 French Revolution into something closer to an ideal-typical model of an ostensibly secular modern state involved not just functional differentiation - and the radical inversion in the

\footnotetext{
${ }^{29}$ J. Casanova, Public Religions in the Modern World, pp. 9-20.

${ }^{30}$ C. Taylor, A Secular Age, p. 2.

${ }^{31}$ Ibid.
} 
relationship - between the religious and the secular spheres: it also opened the way to conflicts along centre-periphery, stratificatory, and even segmentary dimensions of difference. As contrasting patterns of settlement of these conflicts became sedimented in Europe's different corners, the continent's leading Western powers - the Spanish, Portuguese, Dutch, British and French - also began to export versions of these patterns to their growing imperial possessions.

The second set of concepts derives from Pierre Bourdieu's theory of "social fields," which, in contrast to Luhmann's functionalism, directs attention to the ongoing contestation over the dominant "principle of vision and di-vision", through which the social world is perceived and classified. Such contestations are seen to take place within, as well as between, fields - including especially those involving the religious and political fields. Bourdieu suggests three different levels of conflict of particular relevance here:

1. within the religious field (inter-religious but also involving conflicts between religious and other normative communities, for example secular civic republicans)

2. within religious communities (intra-religious)

3. between the religious and non-religious fields (conflicts between religious and non- or antireligious actors). ${ }^{32}$

The conflicts to which the modern state with its means of coercion and consent is a party are not limited to conflicts concerning the proper relationship between the religious and non-religious fields, the principal focus of classical secularization theory. Of course, contestations around this particular conflict line are prevalent in all case studies, but Bourdieu's approach also directs attention to the existence of contestations about the proper place of religion in public life that occur between religious communities (inter-religious competition, as between Hindus and Muslims in India) and within religious communities (intra-religious struggles, as between Sunnis and Shias in Pakistan, or between secular and orthodox Jews in Israel). ${ }^{33}$

Combining the conceptual tools of Luhmann and Bourdieu, one can then locate all four types of Luhmann's differentiations across Bourdieu's three different levels of conflict so generating a

\footnotetext{
${ }^{32}$ In A Secular Age, the utility of these distinctions between levels can be illustrated by their apparent relevance to examples Taylor himself presents: Europe's $16^{\text {th }}$ and $17^{\text {th }}$ century wars of religion (level 1), the struggles over religious dissent and non-conformity occurring more or less openly in Europe's early modern confessional states (level 2), and the conflicts between Enlightenment secularists and the defenders of religious institutions and traditions (level 3).

${ }^{33}$ The centrality of contestations with their implicit focus on power relationships is shared by Taylor who describes his aim in A Secular Age as 'to criticize, and perhaps replace, a widespread understanding of secularity as the inevitable by-product of modernization, however this is understood. Generally it is seen as consisting of processes like economic growth, industrialization, social and geographical mobility; urbanization, the development of science and technology, the advance of instrumental reason, and the like. Various tellings of the story of how we have become carry this sense of secularity as an inevitable consequence. To challenge this, you have to tell another story. Hence the length of the book. (ASA: 301).
} 
twelve-cell matrix of types and levels of religious and secular-religious contestations. Conflicts around secularization may manifest themselves as

- First-level, segmentary, centre-periphery, stratificatory, or functional dimensions of difference within the religious field,

- Second-level, segmentary, centre-periphery, stratificatory, or functional dimensions of difference within religious communities,

- and third-level, segmentary, centre-periphery, stratificatory, or functional dimensions of difference between the religious and non-religious fields.

Table 1: Patterns of Religious and Secular/Religious Contestation

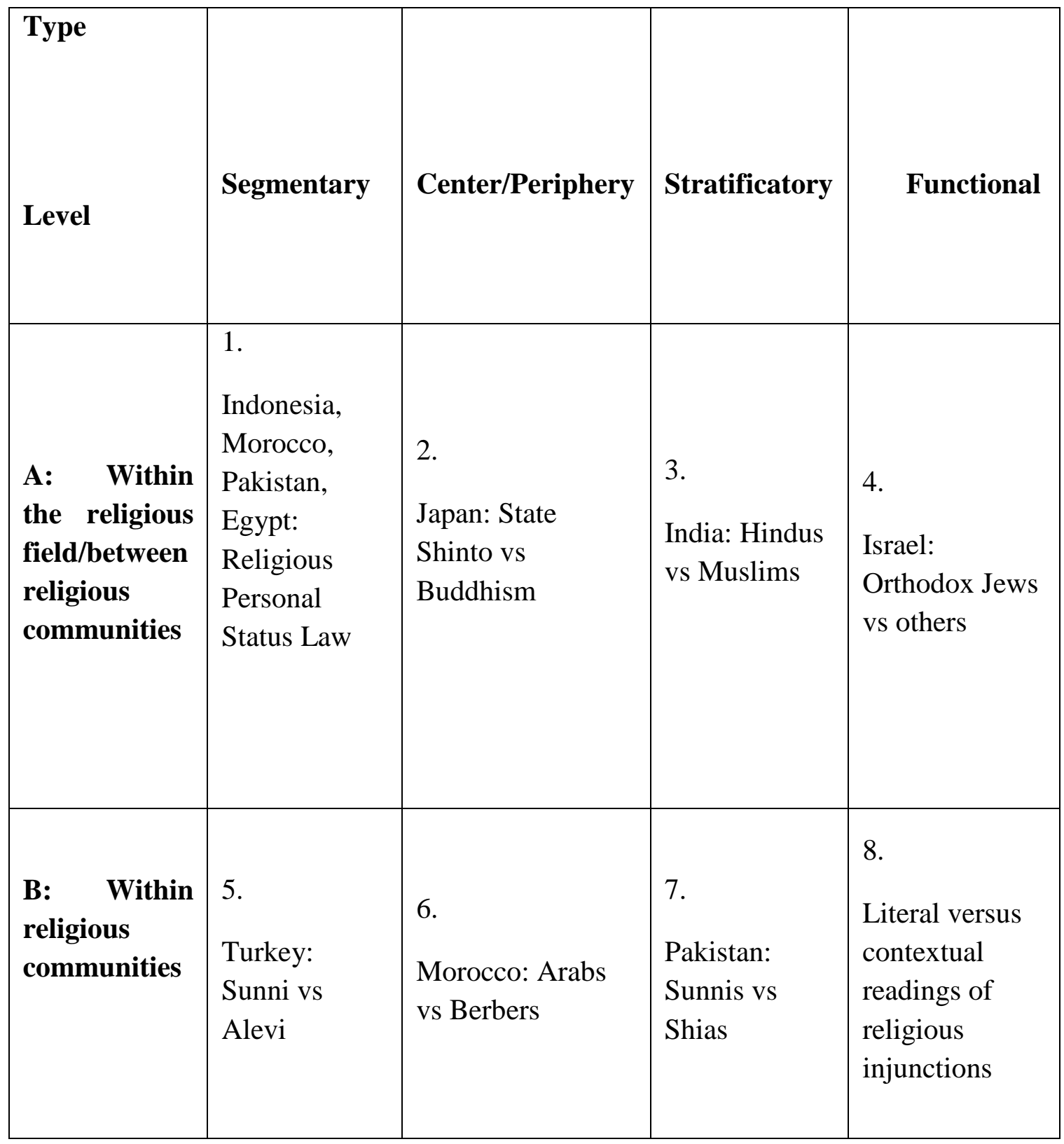




\begin{tabular}{|l|l|l|l|l|}
\hline & & & & \\
$\begin{array}{l}\text { C. Between } \\
\text { the religious } \\
\text { and non- } \\
\text { religious } \\
\text { fields }\end{array}$ & $\begin{array}{l}\text { Latin } \\
\text { Christendom] }\end{array}$ & Turkey: laiklik & $\begin{array}{l}\text { Iran: 1979 } \\
\text { revolution }\end{array}$ & $\begin{array}{l}\text { China: Official } \\
\text { Marxism vs. all } \\
\text { religion }\end{array}$ \\
\hline
\end{tabular}

Crosscutting the two typologies yields a matrix generated by types and levels of differentiation and contestation, which provides a schematic overview of the variety of the 11 cases covered in the volume. The attributions indicated in the table can only be illustrative of important aspects of the patterns of contestation identified across the cases; they cannot be exhaustive or comprehensive, given the complexities indicated in the case studies themselves - any attempt to make the table so would render it unreadable and involve attributing different aspects of individual cases to a large number of cells. China, for example, could be represented in at least seven of the twelve cells; instead, here it is presented alongside the USSR as a case of a secularist state committed by its policies to confining religion, -- as locally interpreted - to the private realm. No attempt has been made in the volume to capture or study all types equally as if to provide a comprehensive analysis preparatory to the sort of 'global generalisation' Taylor suggests might one day be possible. But it does constitute a beginning.

\section{A. Examples of conflicts within the religious field (inter-religious, but also between religious and other normative communities):}

1) Some of the chapters cover cases of segmentary conflict over physical or social space between rival religious and/or ideological communities. India, Israel and all Muslim-majority cases included (except for Turkey) feature separate personal status laws for different religious groups that the state recognizes as such. Here segmentary differentiation has occurred in personal status so as to deal with tensions that otherwise might lead to conflict.

2) Other cases illustrate the dynamics of center/periphery conflicts over, for example, cultural assimilation/autonomy between communities unequally placed relative to centres of power and influence. To take the case of Japan, the state elites of the Tokugawa Shogunate supported Buddhism on grounds of its social utility even though the Confucian-oriented political leaders of the period did not tend to hold Buddhist teachings in high esteem. State elites publicly supported Buddhism as a way to regulate the populace but privately were contemptuous of it. Buddhism eventually lost its pre-eminent status to State Shinto in the $20^{\text {th }}$ century, which became an important element in the Meiji campaign to promote morality through ritual in the formation and discipline of imperial subjects.

3) Other chapters exhibit cases of stratificatory conflict over rank and status between communities placed in essentially unequal circumstances as minorities facing large and cohesive majorities. A leading case here concerns the relations between the dominant Hindu majority and 
the large Muslim minority in India, as these have again become a focus of contestation in recent decades with the rise of the BJP. In this, India's Sikh and Christian communities are also implicated despite the distinctive pattern of 'principled equidistance' of the state from all religious communities which the Indian judiciary has attempted to defend.

4) Israel presents a case of the coexistence of several main strands of Judaism: Orthodox, reform, ultra-orthodox, haredi and, not least, secular Judaism. As the case study makes clear, the tensions between these - and most centrally between secular and Orthodox Jews - at the time of the foundation of the state resulted in an effective stalemate over some key issues which led to a tradeoff of functions between a secular leadership in the state and the Orthodox rabbinate in the religious field. This is most clearly observed in the structure of the courts, with personal status issues, including marriage, conversion and some property matters being judged in religious instead of in state courts. This functional division of labour has continued to give rise to tensions within the Jewish majority of the country's population which has resonated in the country's electoral battles between parties adopting contrasting stands. Accordingly, Israeli secularity has been partly held in check. These contestations can be seen to exemplify all three levels of conflict but to the extent that they involve issues of who counts as a Jew, they can be interpreted to resonate inter- (as much as intra-) religious tensions.

\section{B. Examples of conflicts within religious communities (intra-religious):}

5) A classic case of segmentary conflict between orthodox and heterodox theologies or creeds is illustrated in the case of Turkey, where the tensions between the dominant Sunnis and a large, dispersed minority of Alevis has continued to agitate both secular and religious thinking, with the Alevis typically supporting a secularist ethic which might help protect them from impositions arising from the Sunni majority. As the chapter on Turkey shows, public sphere secularity (laiklik) - which was promoted by the Kemalist regime via programmes of what is sometimes called a hard, assertive, or aggressive form of secularism - has over the last two decades led to a backlash as the ruling Justice and Development Party (AKP) has pushed illiberal agendas with wide public support.

6) A center/periphery conflict within religious communities is exemplified by the case of Morocco, where the Arab centre with its symbolic head, the King as the "Commander of the Faithful,' is counter-posed to the Berbers located in the country's periphery. Although, as the case study points out, there have in the past been attempts to Christianize the Berbers, the conflict remains a largely intra-religious one among Muslims which reverberates differential positions along a centre-periphery dimension with all its implications for status and material advantages favouring denizens of the Arab centres, particularly the urban areas located there.

7) An important case of intra-religious conflict along stratificatory lines can be identified in Pakistan where minority Shias suffer particularly high levels of disadvantage. (In this they share a common fate with the much smaller minorities of Pakistan's Christians, Jews, Hindus and Sikhs which articulate inter-religious conflicts.) The case study argues that 'Sunnization' policies after Zia-ul-Haq should be seen not so much as the abandonment of secularism as instead the implanting of an ethno-religious form of secularity which can be identified in contrast to Taylor's three Secularities as a Secularity IV. 
8) Examples of conflicts across lines of functional differentiation between narrower and broader construals of religious traditions, and ideas about the proper role of the state in upholding these can be found in all the Muslim-majority cases covered in the volume. The types of conflict have revolved around such questions as whether the state should stipulate the beginning and end of Ramadan, regulate the availability of divorce, or license the activity of religious police in upholding locally required standards of dress and behavior. The labeling of the competing views on issues of this sort as literal versus contextual, or narrower versus broader varies relative to who is doing the labeling but the existence of such a dimension of differentiation would appear to be universal and in many cases very prominent in a way which is rarely to be found in the main majoritarian religious traditions of contemporary Europe.

\section{Examples of Conflicts between the religious and non-religious fields:}

9) The absence from the table of a leading case in our chapters of segmentary conflict regarding the relationship between the religious and non-religious fields is symptomatic of the fact that this type of conflict requires a significant level of rivalry between holders of authority in the religious and non-religious fields respectively and as such can only apply to a situation before the emergence of the modern state. In medieval Christendom the differentiation between separate secular and religious jurisdictions comes to mind, which also distinguished between significant sections of the population, with the church's jurisdiction reaching beyond ordained officials to include those who lived and worked on the large ecclesiastical estates. From Augustine's "two cities" through Marsilius' "two swords" and even surviving vestigially in Luther's "two kingdoms", the distinction was a common basis for division. It might even be argued that the segmentary principle still has champions today, both amongst political liberals, advocating a strict "separation of church and state", but also amongst some religious sectarians, who jealously defend the autonomy of their communities. Associating these positions with the segmentary principle is misconceived, however, even though the rhetoric may suggest otherwise, as the stratificatory conflicts between the religious and political fields have been won by the latter. It is the state that determines the relationship between religion and politics in the contemporary world, even in countries governed by religious authorities, like contemporary Iran.

10) Aspects of a center/periphery conflict between state-centred secularism and a majority religious tradition strongly entrenched in the periphery were present in Turkey with its distinctive tradition of Kemalist laiklik borrowed from the French model. The central node is only in part geographically specific (Ankara, which was preferred by Atatürk to multi-religious and metropolitan Istanbul); it can be defined more particularly, following Shils, as involving a concentration of state power which was until recently largely insulated from the large mass of the rural and small-town population with their strong religious traditions.

11) Stratificatory conflicts involving the subordination by secular elites of cultural-religious groups and traditions have been exemplified in all of the cases reviewed. One of the most striking differences between the approaches adopted in our case studies and Taylor's account is that the encounter with the west typically helped political administrations to win the stratificatory contest with religion within a relatively short time frame. Whether colonized or not, "religion" and "state" 
in our case studies were never involved as equal competitors in a struggle over influence. Rather, religion, like any other social element, was subordinated to the interests of political power, first colonial or imperial power, later that of the emerging nation-state. It was the state in whose hands it lay to regulate religion, and it often over time developed ways to regulate traditional strongholds of religious autonomy, such as (religious) law, and (religious) education. It is here that the issue of differential burdening becomes most apparent, as remnants of religious law remain bones of contention between state and social elites in all Muslim-majority cases and in Israel. Nikkie Keddie has observed that "Islamic history is different from Western Christian history, partly because modernizing trends began earlier and have been more gradual in the West, and also because Islam has not had a strong secular legal tradition. These are two of the factors that have made secularization more difficult and contentious in recent decades in the Islamic world than in the West, while all the main scriptural monotheistic religions have been more resistant to secularization than have other religious traditions. ${ }^{, 34}$ We noted earlier that contestations around Secularity I are particularly apparent in the Muslim world and Israel, as both Islam and Judaism may be interpreted as placing more demands on public law than is the case in Christianity, Buddhism or Hinduism. Like Keddie, we find that the non- and polytheist societies have embraced secularization with less resistance than those of Eastern Christianity, Judaism and Islam.

12) The most striking cases of functional conflict arising around the differentiation of the religious and non-religious fields are found in the Russian, Turkish and Chinese cases. The radical marginalization for long periods of time of indigenous religious traditions, institutions, and practices relied on a sharp differentiation between the collection of all public authority in state or party organisations and the subjugation and, at times, virtual elimination of independent religious authority. The revolutionary secularist project only partly involved an inversion of previous patterns of state-religious relations, since in all three cases religious institutions had long been subjected to state authorities; the differentiation and subsequent control of the religious field by the political was however new and involved the stripping out of the sacral claims of the previously established state authorities.

In Russia, the attempt after the Bolshevik revolution of October 1917 to remove all references to religion from the public sphere involved a radical reversal of the predominant pattern of the Tsarist ancién regime. Propaganda and pressure on leading church officials became important tools in the campaign against the Church and religion generally. This intensified during the 'Great Terror'; Froese quotes one former Soviet official who maintained that 85,300 priests, monks and other religious were executed in 1937, 21,000 in 1938 and 3,900 between 1939 and 1941. With the installation of the New Learning system in China, Confucianism had lost its monopolistic position in the education sector, maintaining little place in the secularized national teaching program. Confucian classics were henceforth treated as objects of philosophical and historical studies, rather than carriers of holy knowledge about moral norms and political legitimacy. In Turkey's 1924 revolution, religious educational institutions were closed, and religious law and jurisprudence replaced by secular codes of law. The wearing of religious garb was prohibited and religious organizations, including Sufi orders, closed down.

\footnotetext{
${ }^{34}$ N.R. Keddie, Secularism and the State: Towards Clarity and Global Comparison, http://newleftreview.org/static/assets/archive/pdf/NLR22202.pdf, p. 27.
} 


\section{Concluding Observations}

The case studies illustrate a wide variety of patterns of resistances to, or accommodations of, secularity of the Western variety that demonstrate the emergence beyond the West of multiple secularities in a globalized context supportive of multiple modernities. It has been the purpose of this article to indicate the range of these patterns and to suggest how they might be accounted for, namely by reference to the history of underlying tensions, conflicts, and contestations arising out of contrasting sets of oppositions within and between groups defined by religion, including of course those that hew to a secularist position of denying any special consideration of religious claims. Secularization in the sense of differentiation between the political and religious spheres has occurred in all eleven cases, though it has not led in all cases to the evacuation of religion from public life and related areas (Taylor's Secularity I). In fact, religion retains a presence in the personal law of all included cases but Turkey, Russia, China and Japan. In some, it is also present in the notion of political authority, such as in Iran, and to a lesser extent, in Morocco. What about Secularity III, the notion of secularity of particular interest to Taylor? Has the option not to believe become widely acceptable in the included case studies? The crude answer is no. In none of the Muslim majority countries is it entirely without legal and social consequence to declare oneself a non-believer. In India, Israel, Japan, Russia and Turkey, Secularity III does exist for segments of the population, though the choice to not believe is not a value appreciated by society at large.

In all our cases, the conditions of belief have been highly influenced by contestations around Secularity I. Following Gorski in our volume, we have schematized these contestations drawing on tools provided by Luhmann and Bourdieu. This schematization does not permit of confident conclusions about which types of contestation result in more or less stable patterns of resolution, or result in more or less satisfactory outcomes in terms of human rights, freedoms and human flourishing. Nonetheless, some partial conclusions can be identified. It is for example a striking observation that in Turkey the salience of the ongoing struggles around both Secularity I and III has nearly exclusively been located on the boundary between the religious and non-religious fields, deriving from the fact that since 1924 religious authority has been almost entirely state-defined and regulated. On the other hand, recent events in Turkey (as of early 2015) raise considerable doubts about the stability of the current - or other emergent -settlements with all their implications for the likelihood of a satisfactory resolution of the dilemmas associated with the guarantee of freedom both for and from religion. The most stable cases among the eleven in terms of religion-state relations are those of Japan and Indonesia. It may be no accident that both states 'invented' a panreligious ethos, Shinto and pancasila respectively, that serves the simultaneous purpose of promoting nation-building, while allowing all recognized religions a protected space within which to flourish. As such, both ethoi promote social cohesion and provide positive freedom of religion. On the other hand, the freedom to not believe (freedom from religion), with its associated characteristics of doubt, search and nihilism, is presumably too precarious for the state to openly accommodate or cater for. 